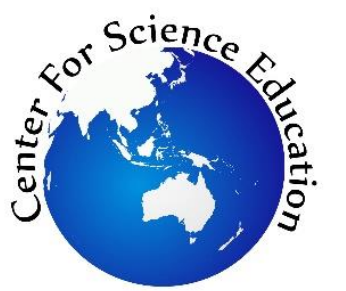

Tersedia online di EDUSAINS

Website: http://journal.uinjkt.ac.id/index.php/edusains

EDUSAINS,13(2), 2021, 153-164

Research Artikel

EDUS: $(\mathbb{1}$;

\author{
PENGEMBANGAN E-MODUL PEMBELAJARAN KIMIA BERBASIS SETS \\ (SCIENCE, ENVIRONMENT, TECHNOLOGY, SOCIETY) PADA MATERI SIFAT \\ KOLIGATIF LARUTAN
}

\title{
DEVELOPMENT OF SETS-BASED CHEMISTRY LEARNING E-MODULES (SCIENCE, ENVIRONMENT, TECHNOLOGY, SOCIETY) ON COLLIGATIVE PROPERTIES OF SOLUTIONS
}

\author{
Rahmawati Maharni $^{*}$, Burhanudin Milama ${ }^{2}$, Rizqy Nur Sholihat ${ }^{3}$ \\ ${ }^{1,2,3}$ Syarif Hidayatullah State Islamic University, Indonesia \\ rahmawati.maharni16@mhs.uinjkt.ac.id
}

\begin{abstract}
This study aims to produce an e-module for learning chemistry based on SETS (Science, Environment, Technology, Society) on the colligative properties of solutions, and to find out students' responses to the emodule. This study uses a 4-D model (define, design, development, and disseminate) which is limited only to the development stage. The instruments used in this research are needs analysis questionnaire, student analysis questionnaire, module content validation sheet, and student response questionnaire sheet. The validation of the content of the module was carried out by 2 instructional review experts and 1 practitioner. Based on the validator's assessment, a valid and worthy module was produced to be tested. The e-module trial phase was carried out on 35 students of class XII MIPA at SMAN 4, South Tangerang City. Based on the student response questionnaire, obtained a percentage of $82.5 \%$ in the SETS-based learning aspect which is included in the very good category. Overall, there was a positive response to the developed e-module with an average percentage of $82.93 \%$ which was included in the very good category and was suitable for use as a medium and source of learning in the learning process.
\end{abstract}

Keywords: e-module; chemistry learning; SETS; colligative properties; 4-D Model.

\begin{abstract}
Abstrak
Penelitian ini bertujuan untuk menghasilkan e-modul pembelajaran kimia berbasis SETS (Science, Environment, Technology, Society) pada materi sifat koligatif larutan, serta mengetahui tanggapan siswa terhadap e-modul tersebut. Penelitian ini menggunakan model 4-D (define, design, development, dan disseminate) yang dibatasi hanya sampai tahap development. Instrumen yang digunakan dalam penelitian ini yaitu angket analisi kebutuhan, angket analisis peserta didik, lembar validasi isi modul, dan lembar angket respon siswa. Validasi isi modul dilakukan oleh 2 orang ahli kajian instruksional dan 1 orang praktisi. Berdasarkan penilaian validator, dihasilkan modul yang valid dan layak untuk diuji coba. Tahap uji coba $e$-modul dilakukan terhadap 35 orang siswa kelas XII MIPA di SMAN 4 Kota Tangerang Selatan. Berdasarkan angket respon siswa, diperoleh presentase sebesar 82,5\% pada aspek pembelajaran berbasis SETS yang termasuk kedalam kategori sangat baik. Secara keseluruhan, diperoleh respon positif terhadap e-modul yang dikembangkan dengan presentase rata-rata sebesar $82,93 \%$ yang termasuk dalam kategori sangat baik dan layak digunakan sebagai media dan sumber belajar dalam proses pembelajaran.
\end{abstract}

Kata Kunci: e-modul; model 4-D; pembelajaran kimia; SETS; sifat koligatif.

Permalink/DOI: http://doi.org/10.15408/es.v13i2.21753 


\section{PENDAHULUAN}

Sumber belajar merupakan salah satu hal penting yang dibutuhkan dalam suatu proses pembelajaran, adanya sumber belajar dapat membantu pendidik dan peserta didik untuk mengoptimalkan keefektifan dalam proses pembelajaran, mendorong kemandirian siswa dalam belajar serta mengembangkan pengetahuan sesuai minat dan bakat siswa (Kelana \& Pratama, 2019). Selain itu, suatu proses pembelajaran akan berkualitas, menarik dan menyenangkan bagi pelajar apabila menggunakan sumber belajar yang baik (Jalinus \& Ambiyar, 2016). Namun, saat ini sumber belajar yang tersedia masih kurang menarik dan mencukupi kebutuhan guru maupun siswa dalam pelaksanaan pembelajaran. Begitu juga dalam pembelajaran kimia, sumber dan media pembelajaran masih terbatas dan belum optimal (Rochayati, 2020).

Hasil analisis kebutuhan terkait proses pembelajaran dan sumber belajar terhadap guru kimia di SMAN 4 Kota Tangerang Selatan menunjukkan bahwa buku kimia yang tersedia di sekolah kurang menarik untuk dibaca dan kurang memenuhi pemahaman konsep bagi siswa. Hal ini dikarenakan buku kimia yang tersedia terlalu banyak penjelasan, bahasa yang sulit dipahami, kurang ilustrasi gambar dan monoton. Dengan demikian, maka dibutuhkan suatu sumber belajar yang bisa mendukung proses pembelajaran serta dapat menarik minat peserta didik untuk belajar.

Salah satu solusi yang bisa dijadikan untuk memenuhi kebutuhan sumber belajar adalah modul. Modul merupakan sumber belajar yang disusun secara terstruktur, terdapat metode, materi, tujuan dan petunjuk belajar serta memuat evaluasi untuk menguji kemampuan siswa melalui latihan yang tersaji dalam modul, sehingga dapat digunakan secara mandiri oleh siswa (Aditia \& Muspiroh, 2013). Modul dibuat sedemikian menarik sehingga dapat memudahkan peserta didik dalam memahami materi pelajaran (Puspitasari, 2019). Oleh karenanya, penggunaan modul sebagai sumber belajar diharapkan dapat meningkatkan keefektifan, kemudahan dan kemandirian siswa dalam proses pembelajaran.
Pada era digital seperti sekarang, diperlukan modul yang bersifat elektronik atau disebut e-modul yang bisa dipelajari melalui gadget, bukan lagi berupa modul cetak. Modul elektronik ialah modul cetak yang dikembangkan dalam bentuk digital dimana strukturnya diadaptasi dari modul cetak (Sugihartini \& Jayanta, 2017). Beberapa kelebihan dari modul elektronik adalah dapat membuat proses pembelajaran lebih menarik dan interaktif, dapat di akses kapanpun dan dimanapun serta dapat meningkatkan kualitas pembelajaran (Cecep \& Bambang, 2013). Selain itu, penggunaan e-modul pada proses pembelajaran juga dapat mengembangkan kemampuan berpikir produktif dan literasi siswa, menciptakan suasana aktif, efektif, inovatif dan menyenangkan bagi siswa serta dapat menumbuhkan kreativitas siswa (Budiarti et al., 2016).

Ilmu kimia memiliki kedudukan yang penting terhadap perkembangan ilmu terapan lain misalnya teknologi, kesehatan, pertanian, dan perikanan (Kustandi \& Sutjipto, 2011). Namun, dalam pelaksanaan pembelajaran tidak sedikit seorang pengajar yang hanya mengikuti isi buku dan kurang mengimplementasikan materi kimia dengan realita kehidupan. Adapun, berdasarkan observasi yang telah dilakukan menunjukkan bahwa guru kurang mengintegrasikan antara materi kimia yang sedang dibahas dengan aspek teknologi, lingkungan, dan masyarakat. Hal itu mengakibatkan siswa kurang mengetahui manfaat pembelajaran sains secara kontekstual, kurang memperhatikan dan peduli terhadap lingkungan, serta kurang bisa mengaitkan konsep yang dipelajari dengan perkembangan teknologi (Wulandari et al., 2016).

Hal tersebut berbanding terbalik dengan salah satu tujuan pembelajaran kimia tingkat sekolah menengah atas. Menurut BNSP tujuan pembelajaran kimia ialah diharapkan peserta didik mampu memahami konsep, prinsip, hukum, dan teori kimia beserta keterkaitan dan implementasinya untuk menyelesaikan persoalan terkait teknologi dan kehidupan sehari-hari. Tujuan pembelajaran kimia lainnya ialah diharapkan peserta didik mampu menumbuhkan 
kesadarannya terkait implementasi ilmu kimia yang bermanfaat dan juga merugikan bagi individu, masyarakat, dan lingkungan serta mengerti pentingnya pengelolaan dan pelestarian lingkungan demi kenyamanan bersama (Sastradewi et al., 2015).

Salah satu pendekatan pembelajaran yang dianggap sejalan untuk merealisasikan tujuan pembelajaran kimia dan sesuai dengan kehidupan sehari-hari ialah dengan menerapkan pembelajaran yang bersifat kontekstual yaitu dengan pendekatan SETS (Science, Environment, Technology, Society). Menurut Aysan dalam (Umaira et al., 2019) pendekatan pembelajaran SETS adalah pendekatan yang menghubungkan antara sains, teknologi, lingkungan dan sosial secara menyeluruh dalam masalah kehidupan sehari-hari. Pendekatan SETS juga dapat menumbuhkan sikap peduli terhadap lingkungan (Mahlianurrahman, 2017). Penggunaan pendeketan SETS dalam proses pembelajaran juga dirasa penting mengingat keberadaan teknologi yang semakin berkembang pesat. Oleh karena itu, dibutuhkan suatu pendekatan yang dapat memadukan ilmu sains dengan aplikasi teknologi, dampaknya terhadap lingkungan dan masyarakat. Sehingga diharapkan siswa memiliki pengetahuan ilmu sains yang saling terintegrasi dengan bidang ilmu lainnya.

Salah satu materi kimia yang memiliki konsep imajiner tetapi memuat contoh yang konkret dalam kehidupan sehari-hari adalah sifat koligatif larutan (Mulyasa, 2008). Salah satu kompetensi dasar (KD) dari materi sifat koligatif larutan yaitu menganalisis fenomena sifat koligatif larutan dalam kehidupan. Berdasarkan KD tersebut siswa dituntut untuk mengamati suatu fenomena sifat koligatif larutan. Kegiatan mengamati ini dapat menimbulkan rasa ingin tau siswa terhadap materi sifat koligatif larutan (Pradnyamita et al., 2019). Selain itu, siswa diminta untuk menunjukkan hasil pencarian informasi terkait penerapan prinsip sifat koligatif larutan dalam kehidupan keseharian. Dengan menerapkan pendekatan pembelajaran SETS pada KD tersebut, maka diharapkan siswa dapat mengintegrasikan konsep sains dalam hal ini sifat koligatif larutan aplikasi teknologi serta dampaknya terhadap lingkungan dan masyarakat sehingga siswa memiliki wawasan yang luas.

Berdasarkan latar belakang yang telah diuraikan, rumusan masalah dalam penelitian ini yaitu "Bagaimana proses pengembangan e-modul pembelajaran kimia berbasis SETS pada materi sifat koligatif larutan?". Untuk lebih memfokuskan penelitian, maka penelitian ini hanya terbatas dan menekankan pada bagaimana proses pengembangan modul elektronik pembelajaran berbasis SETS dan materi yang dibahas yaitu sifat koligatif larutan.

\section{METODE}

Penelitian ini merupakan penelitian pengembangan / Research and Development (R\&D) yang mengacu pada model 4-D yang dikembangkan oleh Thiagarajan, Semmel, dan Semmel. Model 4-D terdiri dari empat tahap yaitu define (pendefinisian), design (perancangan), development (pengembangan), dan disseminate (penyebaran) (Thiagarajan \& Sivasailam, 1974). Namun, penelitian ini dibatasi sampai tahap development saja, karena peneliti hanya mengembangkan dan tidak melakukan penelitian untuk melihat efektivitas kegiatan pembelajaran dengan e-modul yang dikembangkan. Bagan desain penelitian pengembangan yang dilakukan dapat dilihat pada Gambar 1.

Penelitian ini dilaksanakan di SMAN 4 Kota Tangerang Selatanyang dilaksanakan secara online. Analisis kebutuhan dilakukan kepada 2 orang guru kimia dan 5 orang siswa. Validasi isi modul dilakukan oleh 3 orang ahli yang terdiri dari 2 orang dosen kimia sebagai ahli kajian intruksional dan 1 orang guru kimia sebagai praktisi. Proses uji coba terbatas terhadap e-modul yang telah dikembangkan dilaksanakan pada bulan Februari 2021 dengan responden sebanyak 35 orang siswa kelas XII MIPA. 


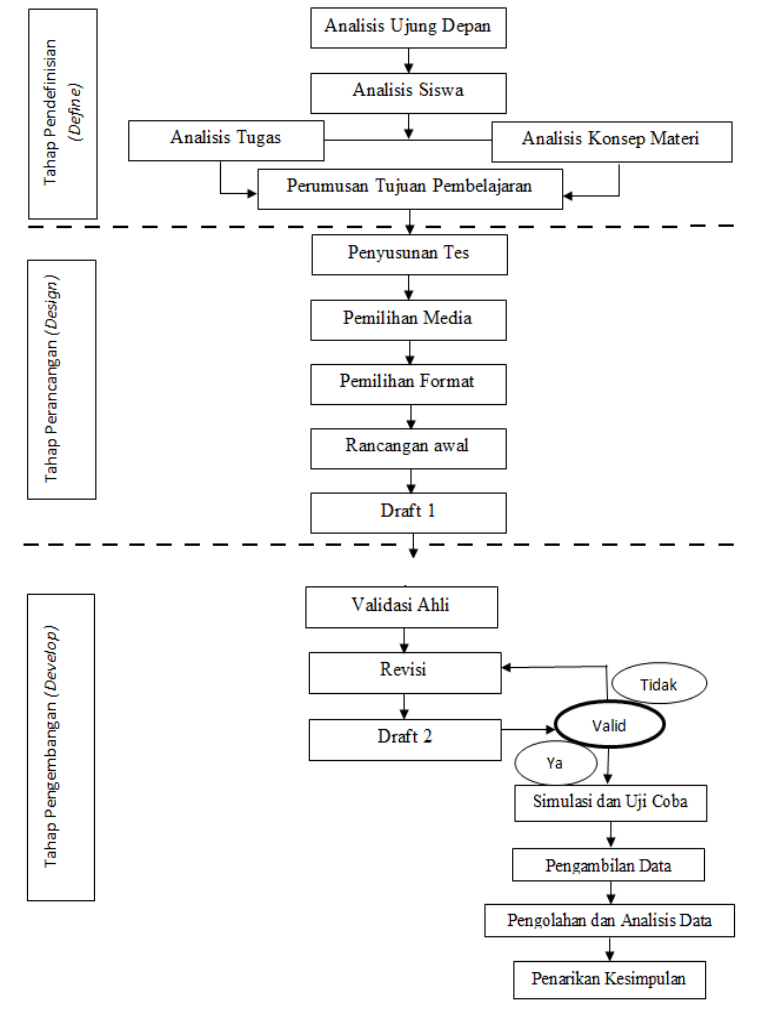

Gambar 1. Bagan Desain Penelitian.

Instrumen yang digunakan dalam penelitian ini adalah lembar angket analisis kebutuhan guru, lembar angket analisis karakteristik siswa, lembar validasi isi modul, dan lembar angket respon siswa. Validasi isi modul bertujuan untuk mengetahui kelayakan produk yang dikembangkan berdasarkan penilaian ahli. Lembar validasi isi modul merujuk pada instrumen penilaian buku teks pelajaran tingkat SMA/MA dari Badan Standar Nasional Pendidikan (BSNP) tahun 2014 yang mencakup penilaian aspek kelayakan isi, penyajian, kebahasaan dan kegrafikan. Sementara itu, lembar angket respon siswa digunakan pada tahap uji coba terbatas untuk mengetahui penilaian siswa terhadap ketepatan dan kecermatan isi, ketercernaan modul, pembelajaran berbasis SETS, penggunaan bahasa dan istilah, perwajahan, serta ilustrasi dan gambar dari modul yang dikembangkan.

Teknik pengolahan data pada lembar validasi ahli menggunakan skala Guttman dengan pilihan jawaban "Ya" dan "Tidak". Jawaban dari narasumber bernilai (1) untuk skor paling tinggi dan bernilai (0) untuk skor paling rendah
(Riduwan, 2007). Sementara itu, pada lembar angket respon siswa digunakan skala Likert dengan 5 pilihan variasi jawaban yaitu sangat tidak setuju (skor 1), tidak setuju (skor 2), kurang setuju (skor 3), setuju (skor 4), dan sangat setuju (skor 5) (Riduwan, 2007).

Data yang diperoleh kemudian ditabulasi dan dihitung presentasenya. Data validitas modul dapat dihitung menggunakan rumus berikut (Akbar, 2016):

$$
\mathrm{Va}=\frac{T s e}{T s h} \times 100 \%
$$

dengan:

Tse $=$ Total skor empirik

Tsh $=$ Total skor maksimal

Rata-rata presentase nilai dari ketiga validator ahli dapat dihitung dengan rumus:

$$
\mathrm{Va}=\frac{V 1+V 2+V 3}{3}
$$

dengan:

$\mathrm{Va}=$ Total nilai rata-rata validator ahli

$\mathrm{V} 1=$ Total nilai validasi dari validator 1

V2 $=$ Total nilai validasi dari validator 2

V3 = Total nilai validasi dari validator 3

Data angket respon siswa terhadap e-modul dihitung menggunakan rumus sebagai berikut (Irmita, 2018):

$$
\text { Presentase }=\frac{\text { Skor } \text { yang diperoleh }}{\text { Skor maksium }} \times 100 \%
$$

Untuk memudahkan dalam menerjemahkan data, skor atau nilai yang telah diperoleh kemudian dikelompokkan ke dalam kriteria yang dapat dilihat pada Tabel 1:

Tabel 1. Kriteria Validasi Ahli

\begin{tabular}{cl}
\hline Interval Skor $(\%)$ & \multicolumn{1}{c}{ Kategori } \\
\hline $85,01-100,00$ & $\begin{array}{l}\text { Sangat valid atau dapat } \\
\text { digunakan tanpa revisi }\end{array}$ \\
$70,01-85,00$ & $\begin{array}{l}\text { Valid atau dapat digunakan } \\
\text { namun perlu direvisi kecil }\end{array}$ \\
$50,01-70,00$ & $\begin{array}{l}\text { Kurang valid, disarankan } \\
\text { tidak dipergunakan karena } \\
\text { perlu revisi besar }\end{array}$ \\
& Tidak valid atau tidak dapat \\
& digunakan \\
&
\end{tabular}

(Akbar, 2016) 
Tabel 2. Kriteria Data Angket Respon Siswa

\begin{tabular}{cl}
\hline Interval Skor (\%) & \multicolumn{1}{c}{ Kategori } \\
\hline $81-100$ & Sangat baik \\
$61-80$ & Baik \\
$41-60$ & Cukup perlu revisi besar \\
$21-40$ & Kurang \\
$0-20$ & Sangat kurang \\
\hline
\end{tabular}

(Riduwan, 2007)

E-modul pembelajaran kimia berbasis SETS pada materi sifat koligatif larutan yang dikembangkan dapat dikategorikan layak digunakan jika hasil perhitungan data angket respon siswa memiliki presentase $\geq 61 \%$ (Prihandono et al., 2017).

\section{HASIL DAN PEMBAHASAN}

\section{Tahap Define (Pendefinisian)}

Tahap pendefinisian dilaksanakan untuk mengetahui masalah dasar dan merumuskan persyaratan pembelajaran melalui kegiatan analisis. Analisis yang dilakukan pada tahap pendefinisian yaitu analisis ujung-depan, analisis karakteristik siswa, analisis konsep, analisis tugas serta merumuskan tujuan pembelajaran (Mi'rojiah, 2016). Analisis ujung-depan dilakukan dengan cara memberikan angket analisis kebutuhan kepada guru kimia yang bertujuan untuk mengenali masalah dasar yang dialami pendidik serta menyimpulkan apakah diperlukan suatu pengembangan perangkat pembelajaran atau tidak. Hasil angket analisis kebutuhan menunjukkan bahwa buku pelajaran yang disediakan oleh sekolah kurang menarik untuk dibaca dan kurang memenuhi pemahaman konsep bagi siswa. Sehingga dibutuhkan suatu pengembangan media dan sumber belajar yang baik dan efektif digunakan dalam pembelajaran.

Langkah selanjutnya yaitu analisis karakteristik siswa. Hasil angket analisis siswa menunjukkan bahwa siswa juga tidak suka membaca buku kimia karena terlalu banyak penjelasan, bahasanya sulit dipahami, kurangnya gambar dan cenderung monoton. Dalam proses pembelajaran, rata-rata siswa juga tidak bersemangat ketika belajar materi kimia. Siswa akan lebih bersemangat jika materi kimia disajikan dengan ringkas dan mudah dipahami, menggunakan media dan metode pembelajaran yang menarik, serta penjelasan materi yang lebih realistis dalam kehidupan sehari-hari. Kebanyakan siswa juga lebih suka memanfaatkan smartphone untuk membuka aplikasi pembelajaran sehingga diperlukan pengembangan sumber dan media belajar yang bersifat elektronik. Modul elektronik bisa dijadikan salah satu solusi agar siswa lebih berminat dengan pembelajaran karena modul elektronik bisa menjadi suatu media interaktif yang bisa disisipi gambar, animasi, audio dan video (Herawati \& Muhtadi, 2018). Selain itu, juga diperlukan pembelajaran kimia berbasis SETS yang mengaitkan pembelajaran kimia dengan teknologi, lingkungan dan masyarakat. Pembelajaran berbasis SETS membuat pembelajaran IPA menjadi lebih bermakna, menarik, dan menyenangkan, karena peserta didik diberi kesempatan untuk mendapatkan ilmu pengetahuan secara mandiri dari sumber belajar yang diintegrasikan dengan teknologi, lingkungan dan masyarakat sehingga siswa tidak cepat lupa dengan pengetahuan yang telah diperolehnya (Widiantini et al., 2017).

Tahap selanjutnya ialah analisis konsep. Langkah ini bertujuan untuk menganalisis konsepkonsep dasar yang akan diajarkan. Analisis konsep terdiri dari analisis kompetensi dasar (KD), penetapan indikator pencapaian kompetensi (IPK) dan analisis materi. Salah satu KD dari materi sifat koligatif larutan memfokuskan pada pengalaman siswa untuk melakukan kegiatan mengamati dan mencari tahu terapan konsep sifat koligatif larutan dalam kehidupan. Sehingga pembelajaran SETS yang menghubungkan konsep sains dengan bidang ilmu lainnya seperti teknologi, lingkungan dan masyarakat dirasa sejalan dengan kompetensi yang diharapkan. Setelah menetapkan KD dan IPK langkah selanjutnya ialah analisis materi berdasarkan KD dan indikator yang telah dibuat. Pada langkah ini peneliti mengumpulkan serta mengidentifikasi sumber-sumber yang dibutuhkan untuk menyusun materi sifat koligatif larutan beserta unsur-unsur SETS, kemudian menghimpunnya kedalam suatu susunan materi belajar. 
Berbekal dari tahap analisis konsep, kemudian dilakukan tahap analisis tugas yang merupakan gambaran cakupan tugas yang akan dimuat dalam modul. Analisis tugas berisi perumusan kegiatan siswa atau latihan-latihan yang akan dilakukan pada setiap kegiatan pembelajaran. Daftar-daftar tugas yang telah disusun berdasarkan KD akan dijabarkan pada tahap perancangan modul. Selanjutnya, dilakukan perumusan tujuan pembelajaran berdasarkan analisis konsep dan analisis tugas yang telah dibuat. Rumusan tersebut ditetapkan untuk setiap kegiatan pembelajaran.

\section{Tahap Design (Perancangan)}

Tahap perancangan terdiri 3 kegiatan yakni penyusunan tes (evaluasi), pemilihan media dan pemilihan format. Dalam penelitian ini, tes disusun dalam bentuk tugas, latihan soal, praktikum serta evaluasi akhir pembelajaran. Tugas, latihan soal dan praktikum terdapat di setiap kegiatan pembelajaran, yang merupakan hasil uraian dari tahap analisis tugas pada tahap define. Tugas yang dimaksud dalam modul ialah kegiatan siswa berdiskusi yang dikemas dalam bentuk "ayo mencari tahu", kegiatan praktikum yang dikemas dalam bentuk "ayo bereksperimen" serta kegiatan siswa untuk menjawab soal-soal yang dikemas dalam bentuk "ayo berlatih".

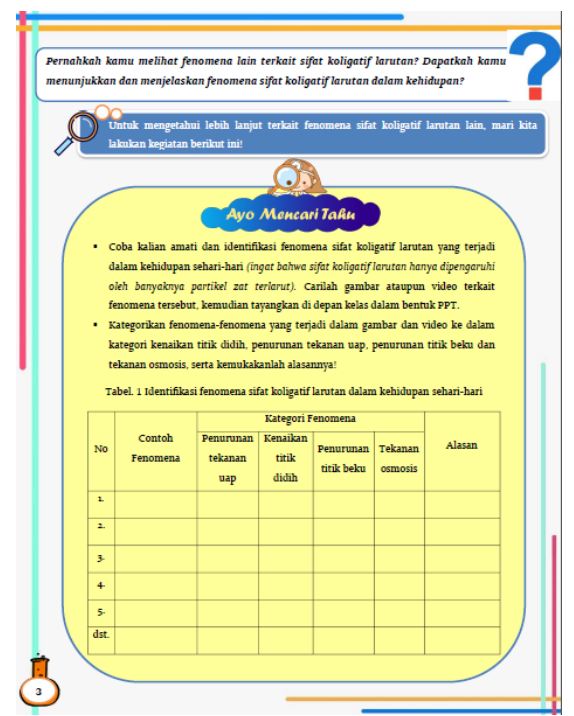

Gambar 2. Contoh tampilan tugas/kegiatan siswa dalam modul
Untuk evaluasi akhir modul terdapat pada bagian akhir modul yang disusun berdasarkan indikator pencapaian kompetensi. Evaluasi akhir pada modul ini berupa tes dalam bentuk pilihan ganda yang dimuat ke dalam google form.

Langkah selanjutnya ialah pemilihan media. Langkah ini dilakukan untuk memilih media yang sesuai untuk membuat e-module pembelajaran. Media yang dipilih dalam pengembangan ini yaitu Flip PDF Corporate versi 2.4.9.31 untuk menghasilkan modul berbentuk elektronik. Pemilihan media tersebut didasarkan atas alasan bahwa e-modul yang dihasilkan dapat memuat dan menampilkan video baik secara offline maupun online, dapat menyisipkan audio atau tautan yang berkaitan dengan pembelajaran serta dapat memindahan halaman dengan cara pageflip.

Setelah penyusunan tugas dan pemilihan media, kegiatan selanjutnya ialah pemilihan format. Pemilihan format berfungsi untuk mengatur tampilan dan struktur modul. Organisasi isi modul untuk setiap kegiatan pembelajaran dibuat serupa yaitu terdiri dari tujuan pembelajaran, uraian materi berbasis SETS, ayo mencari tahu, ayo berlatih, ayo bereksperimen dan rangkuman. Khusus bagian terakhir modul terdapat evaluasi akhir beserta kunci jawaban, daftar pustaka dan glosarium. Pemilihan susunan isi modul tersebut didasari atas teori yang mengatakan bahwa dalam menyusun modul kita perlu menggunakan salah satu variasi secara konsisten agar struktur modul tetap sistematis (Prastowo, 2012). Pada bagian materi, terdapat konsep sifat koligatif larutan beserta penerapan atau wacana terkait konsep tersebut yang dihubungkan langsung dengan aplikasi teknologi, dampaknya terhadap lingkungan serta pengaruhnya kepada masyarakat. Kemudian terdapat tokoh kimia dan bagian "tahukah kamu" untuk memperoleh pengetahuan tambahan terkait materi yang sedang dipelajari.

Langkah selanjutnya yaitu membuat desain isi modul dengan bantuan software adobe photoshop CC 2015. Setelah itu, dilakukan penyususan isi modul sesuai dengan sistematika yang telah ditetapkan pada tahap pemilihan format menggunakan Microsoft Office 2010. Sehingga 
tercipta modul pembelajaran sebagai rancangan awal sebelum dilakukan validasi oleh ahli.

\section{Tahap Develop (Pengembangan)}

\section{a. Validasi Modul}

Validasi modul dilakukan oleh 2 orang dosen ahli dan satu orang guru kimia sebelum pelaksanaan uji coba terbatas. Penilaian kelayakan modul terdiri dari aspek kelayakan isi, kelayakan penyajian, kelayakan kebahasaan, dan kelayakan kegrafisan. Untuk aspek kelayakan isi, pada subaspek pembelajaran berbasis SETS penilaiannya terdiri dari aspek-aspek SETS yaitu kontekstual, menghubungkan antar unsur SETS, aplikasi teknologi, dampak positif dan negatif, serta solusi dari dampak negatif yang ditimbulkan (Rahmah et al., 2017). Selama proses validasi, diperoleh berbagai rekomendasi dari tiga validator yang saling melengkapi dan membangun demi tercapainya kelayakan modul yang dikembangkan. Perbaikan selama proses validasi terhadap isi modul tertera pada Tabel 3 .

Tabel 3. Daftar Revisi Konten

\begin{tabular}{cl}
\hline No. & \multicolumn{1}{c}{ Perbaikan Isi Modul } \\
\hline 1. & $\begin{array}{l}\text { Menambahkan fenomena sifat koligatif larutan } \\
\text { yang terdapat dalam kehidupan sehari-hari. } \\
\text { 2. } \\
\text { Mengeksplorasi hubungan antara konsep sifat } \\
\text { koligatif larutan dengan teknologi, lingkungan, dan } \\
\text { masyarakat secara lengkap. }\end{array}$ \\
3. Memperbanyak penerapan prinsip sifat koligatif \\
larutan kedalam aplikasi teknologi. \\
4. Memperkaya isi modul sehingga memuat \\
pengetahuan terkait manfaat/kerugian penerapan \\
prinsip sifat koligatif larutan bagi teknologi, \\
lingkungan, dan masyarakat. \\
Memperkaya isi modul sehingga memberikan \\
solusi dari dampak negatif yang ditimbulkan terkait \\
penerapan prinsip sifat koligatif larutan. \\
Mengubah ukuran gambar yang ada dalam modul \\
sehingga menjadi proporsional. \\
Menambahkan petunjuk keterangan setiap aspek \\
yang terdapat dalam aplikasi. Contoh: Petunjuk \\
tanda "dampak negatif" "aplikasi teknologi" dll. \\
Menambahkan tabel daftar nilai tetapan penurunan \\
titik beku molal (Kf) dan tetapan kenaikan titik \\
didih molal (Kb) dari sejumlah pelarut. \\
Merubah cover belakang sehingga memiliki \\
kesatuan dengan cover depan.
\end{tabular}

Saran yang paling dominan yaitu terkait aspek-aspek SETS (Science, Environment, Technology, Society) yang harus dikembangkan lagi pada setiap aplikasi/wacana yang terdapat dalam modul sehingga sesuai dan memenuhi karakteristik SETS yang telah disebutkan sebelumnya.

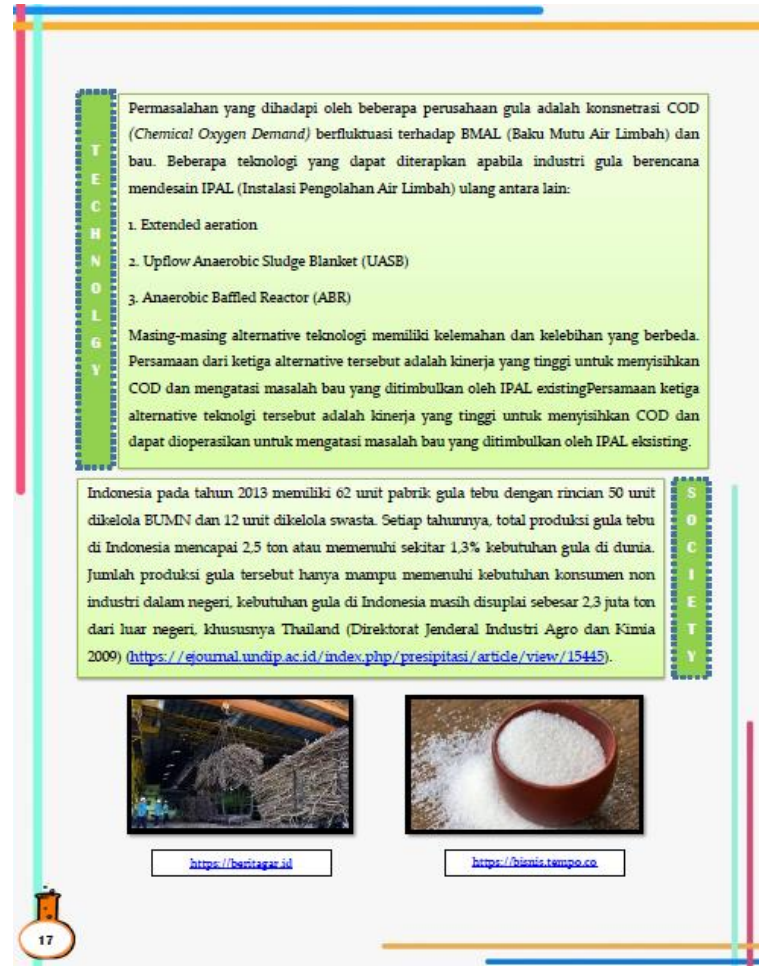

(a)

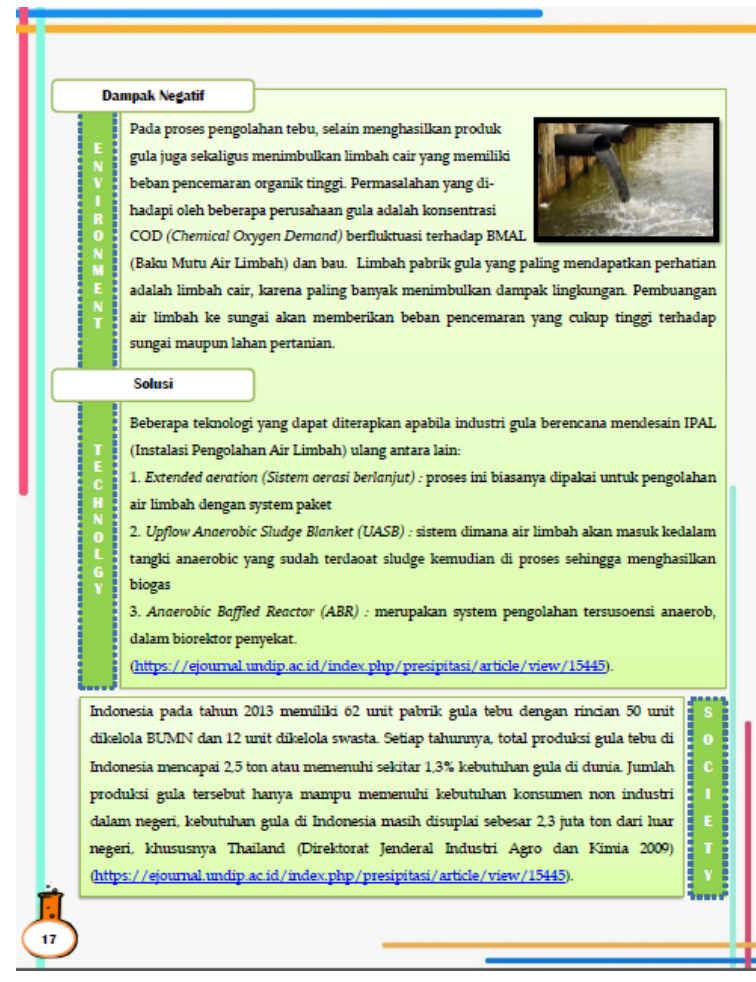

(b)

Gambar 3. Contoh ekplorasi aspek SETS (a) sebelum revisi hanya memuat aplikasi teknologi (b) setelah revisi memuat dampak negatif terhadap lingkungan dari proses produksi serta solusinya menggunakan aplikasi teknologi 


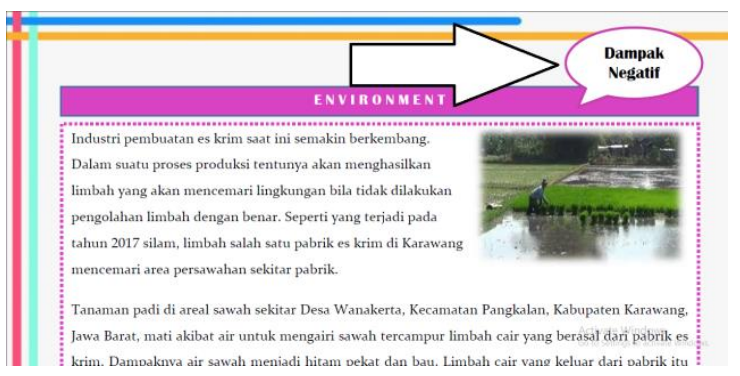

Gambar 4. Contoh pemberian petunjuk keterangan "dampak negatif"

Proses validasi isi modul pada penelitian ini dilakukan sebanyak 2 kali sampai ketiga validator memberikan pendapat "Ya" pada setiap butir validasi atau dihasilkan presentase sebesar $100 \%$. Semakin tinggi nilai validitas semakin baik pula kesimpulan dan tingkat kegunaannya. Sehingga apabila hasil validasi mencapai $100 \%$ maka instrumen tersebut semakin baik digunakan dalam pengambilan data penelitian (Yusuf, 2015).

Tabel 4. Perkembangan Validitas Modul

\begin{tabular}{ccc}
\hline Validator & Validasi I & Validasi II \\
\hline 1 & $90 \%$ & $100 \%$ \\
2 & $98 \%$ & $100 \%$ \\
3 & $96 \%$ & $100 \%$ \\
\hline Rata-rata & $\mathbf{9 4 , 6 7 \%}$ & $\mathbf{1 0 0 \%}$ \\
\hline
\end{tabular}

Tabel 4 menunjukkan hasil akhir penilaian validator terhadap modul yang dikembangkan memperoleh presentase sebesar $100 \%$. Hasil ini menunjukkan bahwa modul yang dikembangkan termasuk dalam kriteria sangat baik dan layak untuk diuji coba.

\section{Uji Coba}

Uji coba dilaksanakan di kelas XII MIPA 3 SMAN 4 Kota Tangerang Selatan dengan jumlah responden sebanyak 35 orang siswa. Untuk mendapatkan data respon siswa, siswa di kelas tersebut diminta untuk mempelajari e-modul yang tersedia dalam bentuk link dan dapat diakses melalui smartphone ataupun laptop kemudian mengisi angket respon siswa yang telah divalidasi dalam bentuk google form. Tujuan utama pelaksanaan uji coba ialah untuk menguji kelayakan dan keterlaksanaan produk (e-modul) yang dikembangkan dalam pembelajaran
(Herawati \& Muhtadi, 2018). Penilaian siswa terhadap e-modul meliputi ketepatan dan kecermatan isi, ketercernaan modul, pembelajaran berbasis SETS, penggunaan bahasa dan istilah, perwajahan, serta ilustrasi dan gambar. Agar memudahkan dalam membaca data angket respon siswa secara menyeluruh, maka data yang diperoleh disajikan dalam bentuk tabel 5 .

Tabel 5. Skor Rata-rata Angket Respon Siswa

\begin{tabular}{|c|c|c|}
\hline Aspek & Indikator & Presentase \\
\hline $\begin{array}{l}\text { Ketepatan \& } \\
\text { Kecermatan Isi }\end{array}$ & $\begin{array}{l}\text { Kesesuaian dengan } \\
\text { tujuan pembelajaran } \\
\text { Kesesuaian dengan } \\
\text { kebutuhan siswa } \\
\text { Kemutakhiran }\end{array}$ & $\begin{array}{l}81,3 \% \\
81 \%\end{array}$ \\
\hline $\begin{array}{l}\text { Ketercernaan } \\
\text { Modul }\end{array}$ & $\begin{array}{l}\text { Kemudahan siswa } \\
\text { mempelajari isi modul } \\
\text { Kelogisan dan } \\
\text { keruntutan isi modul }\end{array}$ & $\begin{array}{l}81,5 \% \\
83 \%\end{array}$ \\
\hline $\begin{array}{l}\text { Pembelajaran } \\
\text { Berbasis SETS }\end{array}$ & $\begin{array}{l}\text { Kesesuaian dengan } \\
\text { karakteristik SETS }\end{array}$ & $82,5 \%$ \\
\hline $\begin{array}{l}\text { Penggunaan } \\
\text { Bahasa \& Istilah }\end{array}$ & $\begin{array}{l}\text { Ragam bahasa } \\
\text { Kejelasan bahasa } \\
\text { penulisan modul }\end{array}$ & $\begin{array}{l}82 \% \\
82 \%\end{array}$ \\
\hline Perwajahan & $\begin{array}{l}\text { Tampilan cover } \\
\text { modul } \\
\text { Tampilan elektronik } \\
\text { modul } \\
\text { Jenis dan ukuran } \\
\text { huruf }\end{array}$ & $82,3 \%$ \\
\hline $\begin{array}{l}\text { Ilustrasi } \\
\text { gambar }\end{array}$ & $\begin{array}{ll}\text { Kesesuaian } & \text { ilustrasi } \\
\text { dan gambar } & \end{array}$ & $85,5 \%$ \\
\hline
\end{tabular}

Pada aspek ketepatan dan kecermatan isi modul, dapat diketahui bahwa kesesuaian modul dengan tujuan pembelajaran dan kebutuhan siswa masing-masing memperoleh skor sebesar 83,5\% dan $81,3 \%$. Hasil tersebut termasuk kedalam kategori sangat baik. Kemudian, pada indikator kemutakhiran juga termasuk kedalam kategori sangat baik dengan presentase sebesar $81 \%$, yang artinya modul elektronik yang dikembangkan sesuai dengan perkembangan zaman.

Untuk aspek ketercernaan modul, diperoleh skor sebesar $81,5 \%$ untuk indikator kemudahan siswa mempelajari isi modul. Sementara itu pada indikator kelogisan dan keruntutan isi modul memperoleh skor sebesar sebesar $85 \%$. Berdasarkan hasil tersebut, menunjukkan bahwa aspek ketercernaan modul sudah termasuk kedalam kategori baik dan layak. 
Pada aspek pembelajaran SETS, skor ratarata yang diperoleh sebesar $82,5 \%$, yang termasuk kedalam kategori sangat baik dan layak digunakan. Hasil tersebut menandakan bahwa modul elektronik yang dikembangkan dianggap telah mempunyai kesesuaian dengan karakteristik pembelajaran SETS. Berdasarkan skor yang diperoleh juga menandakan bahwa e-modul pembelajaran kimia berbasis SETS yang dikembangkan telah memuat aspek-aspek SETS dengan baik, utamanya perihal pemberian informasi terkait konsep sifat koligatif larutan dan aplikasinya yang dihubungkan dengan bidang ilmu lainnya yaitu teknologi, lingkungan, dan masyarakat. Sebagaimana penelitian yang telah dilakukan oleh Ardiansyah et al., (2015) yang menunjukkan bahwa bahan ajar yang dikembangkan mampu dipahami dengan baik oleh siswa serta dapat memberikan ilmu dan wawasan.

Pada aspek penggunaan bahasa dan istilah juga memperoleh respon yang baik dari partisipan dengan skor sebesar $82 \%$. Hasil tersebut dapat ditinjau dari sub aspek ragam bahasa dan kejelasan bahasa penulisan modul yang memperoleh presentase sama yaitu $82 \%$. Bahasa yang digunakan pada penulisan materi isi modul hendaknya bersifat komunikatif, disusun secara singkat, sederhana, jelas, efektif. Penggunaan bahasa yang komunikatif akan membuat pembaca tidak merasa bosan (Lubis et al., 2016).

Sama seperti aspek lainnya, aspek perwajahan atau tampilan memperoleh respon yang baik dari partisipan. Ini dapat ditinjauh dari dari sub aspek tampilan cover modul, tampilan elektronik modul, serta jenis dan ukuran huruf dengan presentase masing-masing yaitu $83 \%$, $82,3 \%$ dan $82 \%$. Artinya, tampilan e-modul secara keseluruhan termasuk kedalam kategori sangat baik. Hal ini didukung oleh penelitian yang mengatakan bahwa aspek kegrafikan yang diantaranya meliputi desain cover serta jenis dan ukuran huruf perlu dibuat menarik. Pemakaian jenis dan ukuran huruf yang memiliki banyak varian dapat membingungkan siswa (Permatasari et al., 2019).

Aspek ilustrasi dan gambar juga mendapatkan skor rata-rata sebesar $85,5 \%$ yang termasuk kategori sangat baik. Hasil tersebut menandakan bahwa adanya ilustrasi dan gambar akan menarik minat siswa untuk membaca modul dan membuat siswa lebih mudah untuk memahami materi pembelajaran yang ada pada modul. Hal ini sesuai dengan pendapat ahli yang mengatakan bahwa sangat dibutuhkan beragam gambar yang dapat menunjang dan memperjelas isi materi. Selain itu, adanya gambar juga dapat menumbuhkan ketertarikan dan rasa semangat siswa untuk mempelajari suatu materi (Prastowo, 2012).

E-modul yang dihasilkan dalam penelitian ini dapat membantu peserta didik dalam dalam memahami materi pelajaran dan menambah ilmu pengetahuan karena e-modul memuat materi secara lengkap dan terintegrasi dengan SETS. $E$ modul juga dapat memudahkan siswa dalam belajar karena aksesnya mudah sehingga memungkinkan siswa untuk dapat belajar secara mandiri kapan dan dimana saja. Gambar 5 merupakan contoh tampilan e-modul pada bagian tujuan pembelajaran dan pendahuluan.

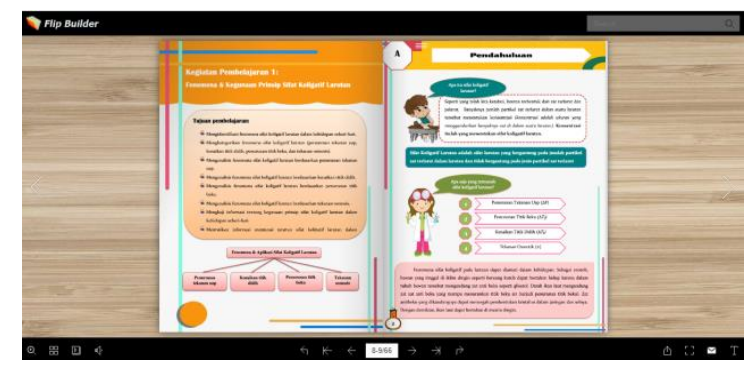

Gambar 5. Contoh Tampilan E-Modul

Secara keseluruhan, e-modul pembelajaran kimia pada materi sifat koligatif larutan yang berbasis SETS memperoleh respon positif dengan rata-rata skor sebesar $82,93 \%$ yang termasuk kedalam kategori sangat baik dan layak digunakan. Hal ini didasari atas penelitian yang mengatakan bahwa apabila hasil perhitungan diperoleh nilai 66\%-100\% maka produk yang dikembangkan tidak perlu direvisi dan layak digunakan (Fausih \& Danang, 2014).

Berdasarkan hasil tersebut dapat dikatakan bahwa baik pendidik dan peserta didik telah menganggap bahwa $e$-modul pembelajaran kimia yang dikembangkan sudah termasuk kedalam kategori sangat baik dan layak digunakan untuk proses belajar mengajar. Hasil ini sama seperti penelitian pengembangan $e$-modul yang dilakukan 
oleh Seruni et al., (2019) dimana menghasilkan $e$ modul dengan kategori baik dengan presentase $84,39 \%$ yang menandakan bahwa modul elektronik yang dikembangkan tersebut dapat digunakan untuk proses belajar mengajar di kelas.

Hasil data angket respon siswa juga menandakan bahwa $e$-modul yang dikembangkan dapat menumbuhkan ketertarikan siswa untuk mempelajari materi sifat koligatif larutan dan memungkinkan siswa untuk dapat belajar dengan mandiri. Hasil tersebut sejalan dengan penelitian yang mengatakan bahwa pembelajaran dengan modul elektronik dapat membawa peserta didik kedalam suasana baru yang sebelumnya belum pernah didapatkan. Dengan demikian, pembelajaran dengan e-modul dapat menumbuhkan keingintahuan siswa dan meningkatkan rasa semangat siswa dalam belajar (Diantari et al., 2018)

\section{PENUTUP}

Penelitian ini bertujuan untuk mengembangkan e-modul pembelajaran kimia berbasis SETS (Science, Environment, Technology, Society) pada materi sifat koligatif larutan dengan menggunakan model 4-D, serta untuk mengetahui respon siswa terhadap e-modul yang dikembangkan. Penelitian ini terdiri dari tahap define yang mencakup analisis ujung-depan, analisis karakteristik siswa, analisis konsep, analisis tugas dan perumusan tujuan pembelajaran. Tahap design mencakup penyusunan tugas, pemilihan media, dan penentuan format. Tahap development berisi kegiatan validasi dan uji coba. Validasi isi modul mendapatkan rata-rata presentase sebesar $97,33 \%$, sementara dari tahap uji coba mendapatkan ratarata presentase respon siswa sebesar $82,93 \%$ yang termasuk kedalam kategori sangat baik dan layak digunakan.

Penelitian pengembangan ini terbatas hanya mengembangkan e-modul pada materi sifat koligatif saja dan di uji coba hanya di satu sekolah. Maka dari itu, terdapat beberapa saran yang diajukan oleh peneliti untuk penelitian kedepannya yaitu perlunya dilakukan penelitian sampai tahap penyebaran (disseminate) dan melaksanakan uji coba dengan jangkauan yang lebih luas untuk mengetahui keefektifan penggunaan e-modul dalam pembelajaran. Selain itu, perlu dibuat e-modul pembelajaran kimia sejenis namun pada materi yang berbeda guna memperbanyak sumber belajar yang terintegrasi dengan SETS. Sebaiknya dibuat e-modul pembelajaran dengan menggunakan platform lain yang lebih interaktif sehingga memungkinkan peserta didik untuk memperoleh feedback secara langsung dalam proses pembelajaran.

\section{DAFTAR PUSTAKA}

Aditia, M. T., \& Muspiroh, N. (2013). Pengembangan Modul Pembelajaran Berbasis Sains, Lingkungan, Teknologi, Masyarakat Dan Islam (Salingtemasis) Dalam Meningkatkan Hasil Belajar Siswa Pada Konsep Ekosistem Kelas X Di Sma $\mathrm{Nu}$ (Nadhatul Ulama) Lemahabang Kabupaten Cirebon. Jurnal Scientiae Educatia, 2(2), 1-20.

Akbar, S. (2016). Instrumen Perangkat Pembelajaran. PT. Remaja Rosdakarya.

Ardiansyah, R., Wahyuni, S., \& Handayani, R. (2015). Pengembangan Bahan Ajar Berbasis Science, Environment, Technology, Society (SETS) dalam Pembelajaran Fisika Bab Alat Optik di SMA. Jurnal Pendidikan Fisika, 4(1).

Budiarti, S., Nuswowati, M., \& Cahyono, E. (2016). Guided Inquiry Berbantuan EModul untuk Meningkatkan Keterampilan Berpikir Kritis. Journal of Innovative Science Education, 1(1), 1-9.

Cecep, K., \& Bambang, S. (2013). Media Pembelajaran Manual dan Digital. Penerbit Ghalia Indonesia.

Diantari, L. P. E., Damayanthi, L. P. E., Sugihartini, N. S., \& Wirawan, I. M. A. (2018). Pengembangan E-Modul Berbasis Mastery Learning Untuk Mata Pelajaran KKPI Kelas XI. Jurnal Nasional Pendidikan Teknik Informatika (JANAPATI), 7(1), 33. 
Fanny Sastradewi, P., Wayan Sadia, I., \& Wayan Karyasa, I. (2015). Pengembangan Perangkat Pembelajaran Kimia Yang Menerapkan Model Problem Based Learning Untuk Meningkatkan Pemahaman Konsep Siswa. 5, 1-12.

Fausih, M., \& Danang, T. (2014). Pengembangan Media E-Modul Mata Pelajaran Produktif Pokok Bahasan "Instalasi Jaringan LAN (Local Area Network )" Untuk Siswa Kelas XI Jurusan Teknik Komputer Jaringan Di SMK Negeri 1 Labang Bangkalan Madura. Jurnal Mahasiswa Teknologi Pendidikan Teknik Informatika, 05(3), 1-9.

Herawati, N. S., \& Muhtadi, A. (2018). Pengembangan modul elektronik (e-modul) interaktif pada mata pelajaran Kimia kelas XI SMA. Jurnal Inovasi Teknologi Pendidikan, 5(2), 180-191.

Irmita, L. U. (2018). Pengembangan Modul Pembelajaran Kimia Menggunakan Pendekatan Science, Technology, Engineering and Mathematic (STEM) Pada Materi Kesetimbangan Kimia. Orbital: Jurnal Pendidikan Kimia, 2(2), 27-37.

Jalinus, N., \& Ambiyar. (2016). Media dan Sumber Pembelajaran Edisi Pertama. Kencana: Jakarta.

Kelana, J. B., \& Pratama, F. (2019). Bahan Ajar IPA Berbasis Literasi Sains. Bandung: Lekkas.

Kustandi, \& Sutjipto. (2011). Media Pembelajaran Manual dan Digital. Bogor: Ghalia Indonesia.

Lubis, M. A., Desnita, D., \& Permana, A. H. (2016). Pengembangan Buku Pengayaan Pengetahuan "Kajian Fisis Batubara" Untuk Siswa Sma.

Mahlianurrahman. (2017). Pengembangan Perangkat Pembelajaran SETS Untuk Meningkatkan Pemahaman Konsep dan Sikap Peduli Lingkungan Siswa Sekolah Dasar. E-Journal Unipma, 7(1), 1-8.

Mi'rojiah, F. (2016). Pengembangan modul berbasis multirepresentasi pada pembelajaran Fisika di Sekolah Menengah Atas. 217-226.

Mulyasa, E. (2008). Kurikulum yang Disempurnakan. Bandung: PT. Remaja Rosdakarya.

Permatasari, I., Ramdani, A., \& Syukur, A. (2019). Pengembangan Bahan Ajar IPA Berbasis Inkuiri Terintegrasi SETS (Science, Environment, Technology and Society) pada materi sistem reproduksi manusia. Pijar MIPA, 13(3), 74-78.

Pradnyamita, M. I., Tika, I. N., \& Sudiana, I. W. (2019). Pengembangan Lembar Kerja Siswa (LKS) Dengan Model Discovery Learning Pada Materi Sifat Koligatif Larutan. Jurnal Pendidikan Kimia Undiksha, 3(2).

Prastowo, A. (2012). Panduan Krearif Membuat Bahan Ajar Inovatif. Yogyakarta: Diva Press.

Prihandono, T., Wahyuni, S., \& Pamungkas, Z. S. (2017). Development of Module Based on Local Potential Integrated SETS in Junior High School. The International Journal of Social Sciences and Humanities Invention, 4(9).

Puspitasari. (2019). Penerapan Media Pembelajaran Fisika Menggunakan Modul. Fisika, Jurnal Pendidikan, 7(1), 17-25.

Rahma, S. Z., Mulyani, S., \& Masyikuri, M. (2017). Pengembangan Modul Berbasis SETS (Science, Environment, Technology, Society) Terintegrasi Nilai Islam di SMAI Surabaya pada Materi Ikatan Kimia. Jurnal Pendidikan (Teori Dan Praktik), 2(1), 70.

Riduwan. (2007). Skala Pengukuran Variabelvariabel Penelitian. Bandung: Alfabeta.

Rochayati, P. (2020). Pengembangan "Komedi Apik" Sebagai Media Pembelajaran Kimia Materi Sistem Periodik Unsur Siswa SMA/MA Artikel Ilmiah. http://repository.unimus.ac.id

Seruni, R., Munawaoh, S., Kurniadewi, F., \& Nurjayadi, M. (2019). Pengembangan Modul Elektronik (E-Module) Biokimia 
Pada Materi Metabolisme Lipid Menggunakan Flip Pdf Professional. Jurnal Tadris Kimiya, 4(1), 48-56.

Sugihartini, N., \& Jayanta, N. L. (2017). Pengembangan E-Modul Mata Kuliah Strategi Pembelajaran. Jurnal Pendidikan Teknologi Dan Kejuruan, 14(2), 221-230.

Thiagarajan, \& Sivasailam. (1974). Instructional Development for Training Teachers of Exceptional Children: A Sourcebook. Center for Innovation in Teaching the Handicapped Indiana University.

Umaira, R., Haji, A. G., \& Rahmatan, H. (2019). Science Environmental Technology and Society- based Module Development on Petroleum Chemistry to Enhance Student Learning Achievement. 7(2), 88-98.
Widiantini, N. N. A. S., Putra, M., \& Wiarta, I. W. (2017). Model Pembelajaran Sets (Science, Environment, Technology, Society) Berbantuan Virtual Lab Berpengaruh Terhadap Kompetensi Pengetahuan Ipa. Journal of Education Technology, 1(2), 141.

Wulandari, T., Ashadi, A., \& Yamtinah, S. (2016). Pengembangan Modul Pereaksi Kimia Berbasis Sets Pada Mata Pelajaran Analisis Kimia Dasar Kelas X SMK Kimia Industri. Inkuiri, 4(4), 54-60.

Yusuf, M. (2015). Asesmen dan Evaluasi Pendidikan - Pilar Penyedia Informasi dan Kegiatan Pengendalian Mutu Pendidikan. Jakarta: Prenada Media Grup. 